\title{
Penggunaan Larutan Pepaya (Carica papaya) sebagai Larvasida Nyamuk Aedes aegypty
}

\author{
Restu Prastiwi ${ }^{1}$, Anita Dewi Moelyaningrum ${ }^{2}$, Prehatin T.N. ${ }^{3}$ \\ ${ }^{123}$ Bagian Kesehatan Lingkungan dan Kesehatan Keselamatan Kerja \\ Fakultas Kesehatan Masyarakat, Univeristas Jember \\ Email Korespondensi: anitamoelyani@gmail.com \\ DOI : $10.32672 /$ jss.v7i2.1304
}

\begin{abstract}
Dengue Fever is a disease that have the higher patients in indonesia. That caused by dengue virus that transmitted by one of Aedes aegypti mosquito. So in order to reduce the impact of the disease, there are several ways that must be taken. One way of controlling that is to reduce the population of Aedes aegypti mosquitoes is by reducing larval growth by using a solution of papaya leaves as larvacide. Papaya leaves contain tannins of $0.12 \%$. So it is possible to kill larvae. The aim of the research is to analyze the average difference of aedes aegypti larvae death without treatment $0 \mathrm{ml} / 100 \mathrm{ml}(\mathrm{X} 0)$, and give treatment differences $1 \mathrm{ml} / 100 \mathrm{ml}(\mathrm{X} 1), 2 \mathrm{ml} /$ $100 \mathrm{ml}(2), 4 \mathrm{ml} / 100 \mathrm{~m}$ (X3) with observations every 6 hours for 24 hours. This is a true experimental research with posttest only control design. The sample is 10 aedes aegypti larvae instar I for each treatment so totals 240 tail of larvae. The sampling technique is using simple random sampling because the populations are homogen. Data were cllected through by observation of larvae that died for 24 hours then analyzed using Kruskall Wallis test and continued with post Hoc test. The results showed that there were differences between the control group and the treatment group ( $\mathrm{p}<0.05$ ). So the factor that significant be the predictors of larvae mortality is a high of the concentration and duration of observation. More concetration of carica papaya leaf, are given and the length of the observation so the mortality rate of the larva is more high. So the solution of carica papaya leaves is statistically effective start on concertation of $2 \mathrm{ml} / 100 \mathrm{ml}$ (X2) and $4 \mathrm{ml} / 100 \mathrm{ml}$ (X3) with observation time of 12 hours and 24 hours. Keywords: Concentration, Time, Carica Papaya Leaves.
\end{abstract}

Keyword: Larvasida, Carica papaya, Aedes aegipty

\section{ABSTRAK}

Demam Berdarah adalah penyakit dengan penderita tertinggi di Indonesia. Hal itu disebabkan oleh virus dengue yang ditularkan oleh salah satu nyamuk Aedes aegypti. Jadi untuk mengurangi dampak penyakit, ada beberapa cara yang harus ditempuh. Salah satu cara pengendalian yaitu mengurangi populasi nyamuk aedes aegypti adalah dengan mengurangi pertumbuhan larva dengan menggunakan larutan daun pepaya sebagai larvasida. Daun pepaya mengandung tanin $0,12 \%$. Jadi sangat memungkinkan untuk membunuh larva. Tujuan dari penelitian ini adalah untuk menganalisis perbedaan rata-rata kematian larva aedes aegypti tanpa perlakuan 0ml / 100ml (X0), dan memberikan perlakuan 1ml / 100ml (X1), 2ml / 
Restu Prastiwi, Anita Dewi Moelyaningrum, Prehatin T.N

100ml (2), 4ml / 100m (X3) dengan pengamatan setiap 6 jam selama 24 jam. Penelitian ini adalah penelitian eksperimental murni dengan desain kontrol posttest. Sampel pada penelitian ini adalah 10 larva aedes aegypti instar I untuk setiap perlakuan dengan total 240 ekor larva. Teknik pengambilan sampel menggunakan simple random sampling karena populasinya homogen. Data dikumpulkan melalui observasi terhadap larva yang mati selama 24 jam kemudian dianalisis menggunakan uji Kruskall Wallis dan dilanjutkan dengan uji post Hoc. Hasil penelitian menunjukkan bahwa ada perbedaan antara kelompok kontrol dan kelompok perlakuan $(\mathrm{p}<0,05)$. Jadi faktor yang signifikan menjadi penyebab kematian larva adalah konsentrasi dan lamanya pengamatan. Lebih banyak konsentrasi daun pepaya yang diberikan dan lama nya durasi waktu pengamatan sehingga tingkat kematian larva lebih tinggi. Jadi larutan daun pepaya secara statistik mulai efektif pada konsentrasi 2ml / 100ml (X2) dan 4ml / 100ml (X3) dengan waktu pengamatan 12 jam dan 24 jam.

Kata kunci: Larvasida, Carica papaya, Aedes aegipty

\section{PENDAHULUAN}

Nyamuk Aedes aegypti merupakan jenis nyamuk yang dapat membawa virus dengue penyebab penyakit demam berdarah. Nyamuk ini berpotensi untuk menularkan penyakit demam berdarah dengue (DBD). DBD adalah suatu penyakit yang ditandai dengan demam mendadak, perdarahan baik di kulit maupun di bagian tubuh lainnya serta dapat menimbulkan syok dan kematian. Penyakit DBD ini terutama menyerang anak-anak termasuk bayi, meskipun sekarang proporsi penderita dewasa meningkat. Demam Berdarah Dengue (DBD) masih merupakan salah satu masalah kesehatan masyarakat yang utama di Indonesia. Seperti halnya pada Kecamatan Sumbersari Jember, Jawa Timur yang merupakan salah satu daerah endemik DBD terutama pada Kelurahan Sumbersari. Menurut Dinas Kesehatan Kabupaten Jember pada tahun 2015 terdapat 60 kasus DBD. Kemudian pada tahun 2016 di Kelurahan Sumber sari terdapat 23 kasus DBD. Selanjutnya pada tahun 2017 terdapat 39 kasus DBD. Dibandingkan dengan Kecamatan Arjasa, pada tahun 2015 terdapat 31 kasus, selanjutnya pada tahun 2016 terdapat 6 kasus DBD, dan yang terakhir pada tahun 2017 terdapat 4 kasus DBD. (Dinas Kesehatan Kab.Jember, 2017). Jadi dapat disimpulkan untuk Kecamatan Sumbersari di setiap tahunnya menjadi daerah tertinggi untuk kasus DBD.

Berdasarkan data tersebut jumlah kasus DBD cukup banyak. Salah satu cara pengendalian yang dilakukan untuk menurunkan populasi nyamuk aedes aegypti yaitu dengan menurunkanpertumbuhan larva. Pemberantasan dapat dilakukan dengan cara memberi larvasida yang pasti dengan menggunakan larvasida yang ramah lingkungan.Tanaman yang berpotensi sebagai larvasida nabati adalah daun pepaya (Enis W, 2016). Daun pepaya memiliki senyawa tanin. Tanin ini dapat membunuh larva aedes aegypti. Larva yang dipakai pada penelitian ini adalah larva instar 1.

\section{METODE PENELITIAN}

Jenis penelitian yang digunakan dalam penelitian ini adalah penelitian True Eksperimental. Rancangan penelitian ini menggunakan Randomized post test only control group design. Kelompok dibagi menjadi dua bagian diambil secara acak, yaitu kelompok 
percobaan dan kelompok kontrol. Perlakuan dilakukan pada kelompok percobaan. Banyaknya perlakuan dalam kelompok ini adalah 4 perlakuan yaitu perlakuan pertama kelompok kontrol yang tidak diberi larutan daun pepayaatau dengan konsentrasi 0ml/100ml kemudian perlakuan kedua dengan konsentrasi $1 \mathrm{ml} / 100 \mathrm{ml}$, perlakuan ketiga 2 $\mathrm{ml} / 100 \mathrm{ml}$, dan perlakuan keempat $4 \mathrm{ml} / 100 \mathrm{ml}$. Sedangkan untuk kelompok kontrol hanya di pakai sebagai kontrol saja.

Variabel bebas merupakan variabel yang dapat mempengaruhi timbulnya variabel terikat. Dalam penelitian ini, variabel bebas yang digunakan adalah larutan daun pepaya dengan konsentrasi $1 \mathrm{ml} / 100 \mathrm{ml}, 2 \mathrm{ml} / 100 \mathrm{ml}$, dan $4 \mathrm{ml} / 100 \mathrm{ml}$ dan waktu pengamatan selama 24 jam.Dengan pengamatan setiap 6,12,18,24 jam. .Variabel terikat adalah variabel yang dipengaruhi atau yang menjadi akibat karena adanya variable bebas. Variabel terikat dalam penelitian ini adalah mortalitas larva nyamuk Aedes aegypti pada stadium larva instar I.

\section{HASIL PENELITIAN}

Berdasarkan hasil uji spektrofotometri terdapat hasil penelitian yang dilakukan di SIG Laboratory Bogor Jawa Barat, pada tabel di bawah ini yang mengambarkan hasil uji spektrofotometry tanin pada daun pepaya. Kadar tanin pada daun pepaya dalam 100 gram $/ 100 \mathrm{ml}$ aquades didapatkan kadar tanin sebesar 0,12\%

Tabel 1. Uji spektrofotometry

\begin{tabular}{ccc}
\hline Uji Spektrofotometry & \multicolumn{2}{c}{ Kesimpulan } \\
\hline \multirow{2}{*}{ Tanin $(\mathrm{ppm})$} & Simplo & Duplo \\
\cline { 2 - 3 } & 1216.74 & 1206.78 \\
\hline Rata-rata & \multicolumn{3}{c}{$0,12 \%$} \\
\hline
\end{tabular}

(Data Primer, tahun 2018)

Tabel 2. Kematian Larva

\begin{tabular}{|c|c|c|c|c|c|}
\hline \multirow{2}{*}{ konsentrasi } & \multirow{2}{*}{$\begin{array}{c}\text { Pengulangan } \\
\text { Ke- }\end{array}$} & \multicolumn{4}{|c|}{ mortalitas larva (Jam) } \\
\hline & & 6 & 12 & 18 & 24 \\
\hline \multirow{6}{*}{$\mathrm{X}_{0}$} & 1 & 0 & 0 & 0 & 0 \\
\hline & 2 & 0 & 0 & 0 & 0 \\
\hline & 3 & 0 & 0 & 0 & 0 \\
\hline & 4 & 0 & 0 & 0 & 0 \\
\hline & 5 & 0 & 0 & 0 & 0 \\
\hline & 6 & 0 & 0 & 0 & 0 \\
\hline \multicolumn{2}{|c|}{ Rata-Rata Kematian } & 0 & 0 & 0 & 0 \\
\hline \multirow{6}{*}{$\mathrm{X}_{1}$} & 1 & 0 & 0 & 0 & 2 \\
\hline & 2 & 0 & 1 & 1 & 2 \\
\hline & 3 & 0 & 0 & 2 & 3 \\
\hline & 4 & 0 & 0 & 1 & 2 \\
\hline & 5 & 0 & 0 & 0 & 1 \\
\hline & 6 & 0 & 1 & 1 & 1 \\
\hline \multicolumn{2}{|c|}{ Rata-Rata Kematian } & 0 & 0,3 & 0,8 & 1,8 \\
\hline
\end{tabular}


Restu Prastiwi, Anita Dewi Moelyaningrum, Prehatin T.N

\begin{tabular}{|c|c|c|c|c|c|}
\hline \multirow{2}{*}{ konsentrasi } & \multirow{2}{*}{$\begin{array}{c}\text { Pengulangan } \\
\mathrm{Ke}-\end{array}$} & \multicolumn{4}{|c|}{ mortalitas larva (Jam) } \\
\hline & & 6 & 12 & 18 & 24 \\
\hline \multirow{6}{*}{$X_{2}$} & 1 & 0 & 1 & 2 & 3 \\
\hline & 2 & 0 & 0 & 1 & 3 \\
\hline & 3 & 0 & 0 & 0 & 2 \\
\hline & 4 & 0 & 1 & 2 & 2 \\
\hline & 5 & 0 & 1 & 0 & 1 \\
\hline & 6 & 0 & 0 & 2 & 2 \\
\hline \multicolumn{2}{|c|}{ Rata-Rata Kematian } & 0 & 0,5 & 1,2 & 2,2 \\
\hline \multirow{6}{*}{$X_{3}$} & 1 & 0 & 2 & 4 & 5 \\
\hline & 2 & 0 & 0 & 3 & 4 \\
\hline & 3 & 0 & 0 & 3 & 4 \\
\hline & 4 & 0 & 2 & 2 & 3 \\
\hline & 5 & 0 & 1 & 2 & 3 \\
\hline & 6 & 0 & 2 & 3 & 4 \\
\hline \multicolumn{2}{|c|}{ Rata-Rata Kematian } & 0 & 1,2 & 2,8 & 3,8 \\
\hline
\end{tabular}

(Data Primer, tahun 2018)

Berdasarkan pada tabel kematian larva diatas dapat diketahui bahwa pada konsentrasi $0 \mathrm{ml} / 100 \mathrm{ml}$ tidak ada larva yang mati, hal ini karena tidak adanya penambahan larutan daun pepaya (Carica papaya). Pada konsentrasi $1 \mathrm{ml} / 100 \mathrm{ml}$ larva mulai mati pada waktu pengamatan 12 jam dengan persentase sebesar 0,3 pada pengamatan 18 jam sebesar 0,8 dan tertinggi pada pengamatan 24 jam yaitu sebesar 1,8 . Pada konsentrasi $2 \mathrm{ml} / 100 \mathrm{ml}$ larva mulai mati pada waktu pengamatan 12 jam yaitu sebesar 0,5 pada pengamatan 18 jam sebesar 1,2 dan pada pengamatan 24 jam sebesar 2,2. Pada konsentrasi $4 \mathrm{ml}$ larva mulai mati waktu pengamatan 12 jam yaitu dengan persentase 1,2. pada pengamatan 18 jam sebesar 2,8. pada pengamatan 24 jam sebesar 3,8. Sehingga dapat diketahui semakin besar konsentrasi dan semakin lama waktu pengamatan maka tingkat kematian larva Aedes aegypti semakin tinggi. Berdasarkan hasil penelitian dapat diketahui bahwa semakin tinggi konsentrasi maka kematian larva juga semakin besar. Persentase kematian larva tertinggi yaitu pada konsentrasi $4 \mathrm{ml} / 100 \mathrm{ml}$ sedangkan kematian terendah pada konsentrasi $1 \mathrm{ml} / 100 \mathrm{ml}$.

Lama waktu pengamatan juga dapat mempengaruhi kematian larva, berdasarkan tabel diatas, semakin lama waktu pengamatan yang dilakukan maka semakin meningkat persentase kematian larva Aedes aegypti. Berdasarkan tabel tersebut dapat dikatakan bahwa penggunaan larutan daun pepaya menyebabkan kematian pada larva Aedes aegypti hal ini dapat dibuktikan dengan pengamatan pada kelompok kontrol yang tidak terjadi kematian pada setiap pengulangannya. 
Tabel 3. Hasil Uji Normalitas

\begin{tabular}{ccc}
\hline Waktu & Konsentrasi & Sig \\
\hline \multirow{3}{*}{6 jam } & $0 \mathrm{ml}$ & 0,000 \\
& $1 \mathrm{ml}$ & 0,000 \\
$2 \mathrm{ml}$ & 0,000 \\
& $4 \mathrm{ml}$ & 0,000 \\
\hline \multirow{2}{*}{12 jam } & $0 \mathrm{ml}$ & 0,000 \\
& $1 \mathrm{ml}$ & 0,000 \\
& $2 \mathrm{ml}$ & 0,056 \\
\multirow{2}{*}{18 jam } & $4 \mathrm{ml}$ & 0,094 \\
& $0 \mathrm{ml}$ & 0,000 \\
& $1 \mathrm{ml}$ & 0,200 \\
& $2 \mathrm{ml}$ & 0,094 \\
& $4 \mathrm{ml}$ & 0,200 \\
\hline \multirow{2}{*}{24 jam } & $0 \mathrm{ml}$ & 0,000 \\
& $1 \mathrm{ml}$ & 0,200 \\
& $2 \mathrm{ml}$ & 0,200 \\
& $4 \mathrm{ml}$ & 0,200 \\
\hline
\end{tabular}

(Data Primer, tahun 2018)

Tabel 4. Hasil Uji Kruskal Walis

\begin{tabular}{ccc}
\hline Waktu & Konsentrasi & Sig \\
\hline \multirow{2}{*}{6 jam } & $0 \mathrm{ml}$ & \\
& $1 \mathrm{ml}$ & 1,000 \\
& $2 \mathrm{ml}$ & \\
& $4 \mathrm{ml}$ & \\
& $0 \mathrm{ml}$ & \\
\multirow{2}{*}{12 jam } & $1 \mathrm{ml}$ & 0,041 \\
& $2 \mathrm{ml}$ & \\
& $4 \mathrm{ml}$ & 0,001 \\
\hline \multirow{2}{*}{18 jam } & $0 \mathrm{ml}$ & \\
& $1 \mathrm{ml}$ & \\
& $2 \mathrm{ml}$ & 0,000 \\
& $4 \mathrm{ml}$ & \\
\hline \multirow{2}{*}{24 jam } & $0 \mathrm{ml}$ & \\
& $1 \mathrm{ml}$ & \\
\end{tabular}

\section{(Data Primer, tahun 2018)}

Pembahasan

Kematian larva pada waktu pengamatan 6 jam tidak signifikan, hal ini dikarenakan berdasarkan hasil uji Kruskal Wallis diperoleh nilai signifikansi sebesar 1,000. Berdasarkan waktu 6 jam paparan terdapat nilai signifikansi $<0,05$ menunjukkan bahwa terdapat perbedaan kematian pada larva Aedes aegypti sehingga tabel kematian larva pada 
waktu 6 jam dinyatakan tidak signifikan karena nilai p>0,05 sehingga pada waktu 6 jam tidak memberikan efek kematian terhadap larva.

Hasil uji kruskal wallis pada waktu 12 jam. Dapat dijelaskan bahwa kematian larva Aedes aegypti pada waktu 12 jam dengan konsentrasi $0 \mathrm{ml}, 1 \mathrm{ml}, 2 \mathrm{ml}, 4 \mathrm{ml}$ signifikan, hal ini dikarenakan berdasarkan hasil uji Kruskal Wallis diperoleh nilai signifikansi sebesar 0,041. terdapat nilai signifikansi $<0,05$ menunjukkan bahwa terdapat perbedaan kematian pada larva Aedes aegypti dengan perbedaan waktu pengamatan.

Hasil uji kruskal wallis pada waktu 18 jam. Dapat dijelaskan bahwa kematian larva Aedes aegypti pada waktu 18 jam dengan konsentrasi $0 \mathrm{ml}, 1 \mathrm{ml}, 2 \mathrm{ml}, 4 \mathrm{ml}$ signifikan, hal ini dikarenakan berdasarkan hasil uji Kruskal Wallis diperoleh nilai signifikansi sebesar 0,001 . terdapat nilai signifikansi<0,05 menunjukkan bahwa terdapat perbedaan kematian pada larva Aedes aegypti dengan perbedaan waktu pengamatan.

Hasil uji kruskal wallis pada waktu 24 jam. Dapat dijelaskan bahwa kematian larva Aedes aegypti pada waktu 24 jam dengan konsentrasi $0 \mathrm{ml}, 1 \mathrm{ml}, 2 \mathrm{ml}, 4 \mathrm{ml}$ signifikan, hal ini dikarenakan berdasarkan hasil uji Kruskal Wallis diperoleh nilai signifikansi sebesar 0,000 . Terdapat nilai signifikansi< $<0,05$ menunjukkan bahwa terdapat perbedaan kematian pada larva Aedes aegypti dengan perbedaan waktu pengamatan.

Penelitian yang dilakukan pada waktu 6 jam dengan pemberian konsentrasi $0 \mathrm{ml} / 100 \mathrm{ml}, 1 \mathrm{ml} / 100 \mathrm{ml}, 2 \mathrm{ml} / 100 \mathrm{ml}, 4 \mathrm{ml} / 100 \mathrm{ml}$ tidak terlihat kematian larva. Pemberian konsentrasi $1 \mathrm{ml} / 100 \mathrm{ml}$ pada waktu pengamatan 12 jam terlihat kematian sebesar 0,3. Kemudian pada konsentrasi $2 \mathrm{ml} / 100 \mathrm{ml}$ pada waktu pengamatan 12 jam terlihat kematian sebesar 0,5. Dan pemberian konsentrasi $4 \mathrm{ml} / 100 \mathrm{ml}$ pada waktu pengamatan 12 jam terlihat kematian sebesar 1,2. Semakin lama waktu paparan larvasida daun pepaya dan semakin besar konsentrasi yang digunakan maka tingkat kematian larva semakin besar. Pemberian konsentrasi $1 \mathrm{ml} / 100 \mathrm{ml}$ pada waktu pengamatan 18 jam terlihat kematian sebesar 0,8. Kemudian pada konsentrasi $2 \mathrm{ml} / 100 \mathrm{ml}$ pada waktu pengamatan 18 jam terlihat kematian sebesar 1,2. Dan pemberian konsentrasi $4 \mathrm{ml} / 100 \mathrm{ml}$ pada waktu pengamatan 18 jam terlihat kematian sebesar 2,8. Semakin lama waktu paparan larvasida daun pepaya dan semakin besar konsentrasi yang digunakan maka tingkat kematian larva semakin besar.

Pemberian konsentrasi $1 \mathrm{ml} / 100 \mathrm{ml}$ pada waktu pengamatan 24 jam terlihat kematian sebesar 1,8 . Kemudian pada konsentrasi $2 \mathrm{ml} / 100 \mathrm{ml}$ pada waktu pengamatan 24 jam terlihat kematian sebesar 2,2. Dan pemberian konsentrasi 4ml/100ml pada waktu pengamatan 24 jam terlihat kematian sebesar 3,8. Semakin lama waktu paparan larvasida daun pepaya dan semakin besar konsentrasi yang digunakan maka tingkat kematian larva semakin besar.

Berdasarkan hasil uji Kruskal Wallis kematian larva pada konsentrasi ini secara statistik signifikan, hal ini dikarenakan nilai $\mathrm{p}<0,05$ artinya terdapat perbedaaan rata-rata kematian larva terhadap konsentrasi larutan daun pepaya yang digunakan. Kondisi larva yang mati dapat diamati dengan larva yang mengambang diatas permukaan air membentuk sudut 1800 selain itu warna tubuh larva menjadi transparan, gepeng, mengecil dari ukuran semula dan tidak bergerak aktif ketika air digerakkan (Anita, D. M., Anis Y., \& Ellyke. 2018) . Selain itu, perbedaan juga dapat dilihat dari aktivitas larva pada kontrol (K) dengan aktivitas larva yang diberi perlakuan yaitu ketika paparan 3 jam larva yang diberi perlakuan selalu berada dipermukaan air dan berusaha menjauhi dasar, sedangkan larva pada kontrol $(\mathrm{K})$ mereka tetap berada didasar kontainer. Hal ini dikarenakan efek adanya pemberian larutan daun pepaya, dimana menurut Utomo (2010:153) ciri-ciri larva 
Aedes aegypti selalu berada di dasar air karena disebut pemakan makanan di dasar (bottom feeder). Selain itu bentuk tubuh larva yang transparan, gepeng, dan tidak bergerak ketika air digerakkan. Kematian larva terjadi karena dampak dari senyawa tanin hal ini dibuktikan dari penelitian yang dilakukan oleh Luthfi (2019:4) bahwa Tanin dapat menyebabkan penurunan aktivitas enzim protease dalam mengubah asam-asam amino. Senyawa tanin dapat mengikat enzim protease yang menghambat kerja dari enzim tersebut, sehingga proses metabolisme sel dapat terganggu dan larva akan kekurangan nutrisi. Hal ini dapat mengakibatkan pertumbuhan larva terhambat dan jika proses ini berlangsung secara terus menerus maka akan berdampak pada kematian larva. Selain itu menurut penelitian yang dilakukan oleh Najib (2016:45) tanin menekan konsumsi makan, tingkat pertumbuhan dan kemampuan bertahan. Tanin bersifat toksik dan menghalangi serangga dalam mencerna makanan karena dapat mengikat protein yang diperlukan untuk pertumbuhan larva. Kemudian senyawa tanin juga dapat menghalangi serangga dalam mencerna makanan (Jannah, 2009:5). Menurut Hopkins dan Hiiner (2004), tanin menekan konsumsi makan, tingkat pertumbuhan dan kemampuan bertahan. Tanin, kuinon dan saponin memiliki rasa yang pahit sehingga dapat menyebabkan mekanisme penghambatan makan pada larva uji. Rasa yang pahit menyebabkan larva tidak mau makan sehingga larva akan kelaparan dan akhimya mati.Menurut penelitian yang dilakukan oleh Malathi (2015:2) Temuan dari investigasi ini mengungkapkan bahwa daun pepaya (Carica papaya) memiliki larvisidal dan aktivitas pengusir nyamuk Aedes aegypti. Semua bagian tanaman yang diuji sangat efisien dan efektif aksi larvisidanya.

Berdasarkan hasil pra-lab yang yang dilakukan oleh peneliti di dapatkan hasil tanin yang dilakukan 2x pengulangan (duplo).Untuk hasil simplo sebesar 1216,74 ppm dan hasil duplo sebesar 1206,78 ppm. Hasil tanin tersebut didapatkan dari pengujian $100 \mathrm{gr}$ daun pepaya yang dilarutkan dengan aquades sebesar $100 \mathrm{ml}$, untuk mendapatkan konsentrasi $100 \%$. Uji tanin tersebut dilakukan di sig laboratory yang terletak di Kota Bogor - Jawa Barat. Kemudian hasil tersebut di konversi ke persen yaitu sebesar 0,12\%. Sehingga di dapatkan jumlah tanin dalam 100gr daun pepaya, dan $100 \mathrm{ml}$ aquades. Setelah dilakukan pengamatan larutan uji kemudian dilakukan uji eksperimen. Dengan konsentrasi diatas, dilakukan pemaparan terhadap larva dengan larutan sebesar $1 \mathrm{ml} / 100 \mathrm{ml}$ aquades. Dan dalam waktu 6 jam larva sudah tewas tak berdaya. Jadi jumlah kadar tanin yang di paparkan adalah sebesar $0,01 \%$ dan terbukti dapat membunuh larva. Apabila ingin diaplikasikan di bak mandi dengan volume air 1000liter, yang berisi 20 ekor larva dapat diberikan larutan daun pepaya sebesar $500 \mathrm{ml}$ dengan perhitungan kadar tanin sebesar 0,2\% dari 2000gr daun. Berdasarkan latar belakang diatas peneliti tertarik untuk melakukan penelitian tentang penggunaan larutan daun pepaya terhadap larva Aedes aegypti instar 1.

Perbedaan efektifitas larutan daun pepaya terhadap kematian larva Berdasarkan penelitian yang sudah dilakukan diketahui bahwa larutan daun pepaya (carica papaya) dapat menyebabkan kematian terhadap larva Aedes aegypti instar 1 yang diamati selama 24 jam. Kematian larva instar 1 ini dikarenakan larutan daun pepaya (carica papaya) yang dipaparkan ke larva menyebabkan gangguan sistem pernafasan, sistem saraf, sistem pencernaan larva. (Najib, 2017:44). Sehingga dapat disimpulkan bahwa semakin lama waktu pengamatan dan semakin tinggi konsentrasi yang dilakukan maka akan semakin tinggi tingkat kematian pada larva Aedes aegypti instar 1. Karena semakin lama waktu pengamatan dan semakin tinggi konsentrasi yang dilakukan, akan semakin 
banyak kandungan kimia yang akan masuk ke dalam tubuh larva yang menyebabkan ketahanan tubuh larva instar 1 tersebut berkurang sehingga menyebabkan kematian.

Dapat diketahui bahwa pada konsentrasi $0 \mathrm{ml} / 100 \mathrm{ml}$ tidak ada larva yang mati, hal ini karena tidak adanya penambahan larutan daun pepaya (Carica papaya). Pada konsentrasi $1 \mathrm{ml} / 100 \mathrm{ml}$ larva mulai mati pada waktu pengamatan 12 jam dengan persentase sebesar 0,3 pada pengamatan 18 jam sebesar 0,8 dan tertinggi pada pengamatan 24 jam yaitu sebesar 1,8 . Pada konsentrasi $2 \mathrm{ml} / 100 \mathrm{ml}$ larva mulai mati pada waktu pengamatan 12 jam yaitu sebesar 0,5 pada pengamatan 18 jam sebesar 1,2 dan pada pengamatan 24 jam sebesar 2,2. Pada konsentrasi $4 \mathrm{ml}$ larva mulai mati waktu pengamatan 12 jam yaitu dengan persentase 1,2. pada pengamatan 18 jam sebesar 2,8. pada pengamatan 24 jam sebesar 3,8. Sehingga dapat diketahui semakin besar konsentrasi dan semakin lama waktu pengamatan maka tingkat kematian larva Aedes aegypti semakin tinggi. Berdasarkan hasil penelitian dapat diketahui bahwa semakin tinggi konsentrasi maka kematian larva juga semakin besar. Persentase kematian larva tertinggi yaitu pada konsentrasi $4 \mathrm{ml} / 100 \mathrm{ml}$ sedangkan kematian terendah pada konsentrasi $1 \mathrm{ml} / 100 \mathrm{ml}$.

Sehingga dapat diketahui semakin besar konsentrasi dan semakin lama waktu pengamatan maka tingkat kematian larva Aedes aegypti semakin tinggi. Berdasarkan hasil penelitian dapat diketahui bahwa semakin tinggi konsentrasi maka kematian larva juga semakin besar. Persentase kematian larva tertinggi yaitu pada konsentrasi $4 \mathrm{ml}$ sedangkan kematian terendah pada konsentrasi $0 \mathrm{ml}$. Lama waktu pengamatan juga mempengaruhi terhadap kematian larva, berdasarkan tabel 4.1 semakin lama waktu pengamatan yang dilakukan maka semakin meningkat persentase kematian larva Aedes aegypti. Zat yang terdapat didalam daun pepaya yang dapat membunuh larva adalah senyawa tanin. Menurut penelitian yang dilakukan oleh Najib (2016:45) tanin menekan konsumsi makan, tingkat pertumbuhan dan kemampuan bertahan. Tanin bersifat toksik dan menghalangi serangga dalam mencerna makanan karena dapat mengikat protein yang diperlukan untuk

Pertumbuhan larva. Jadi dapat dikatakan bahwa penggunaan larutan daun pepaya menyebabkan kematian pada larva Aedes aegypti hal ini dapat dibuktikan dengan pengamatan pada kelompok kontrol yang tidak terjadi kematian pada setiap pengulangannya. Sehingga berdasarkan uraian diatas dapat diketahui bahwa potensi larutan daun pepaya mulai memberikan efek kematian yang signifikan yaitu pada pengamatan 24 jam, hal ini sesuai dengan penelitian ariesta (2013) semakin lama waktu pengamatan maka kematian larva juga meningkat.

Hasil Penelitian tentang Penggunaan Larutan Daun Pepaya (Carica papaya) Sebagai LarvasidaTerhadap Kematian Larva Aedes Aegypti menunjukkan hasil yang signifikan. Konsentrasi pada setiap perlakuan memiliki perbedaan kematian yang signifikan. Jadi dari penelitian tersebut diketahui bahwa semakin lama waktu paparan larva terhadap larutan daun pepaya semakin besar kematian larva tersebut. Rekomendasi dari penelitian ini adalah perlu modifikasi bentuk supaya dapat diaplikasikan pada air. Karena jika cairan masuk kedalam cairan warna akan berubah menjad hijau pekat. Sehinnga butuh penelitian lanjutan agar dapat diaplikasikan dan dirasakan manfaat nya terhadap kehidupan.

\section{PENUTUP}

\section{Simpulan}

Berdasarkan hasil penelitian dapat dirumuskan bahwa kelomppok kontrol tidak terdapat perbedaan yang signifikan pada kematian larva $(p>0,05)$. Sedangkan pada kelompok perlakuan terdapat perbedaan yang signifikan terhadap kematian larva $(p<0,05)$. 
Pemberian larutan daun pepaya mulai efektif pada kematian larva waktu pengamatan 18 dan 24 jam. Perlu penelitian lanjutan dengan paparan terhadap telur aedes aegypti dan dengan perpanjangan waktu paparan terhadap larva Aedes aegypti selama 48 jam sehingga mengetahui apakah larva mati secara keseluruhan.

\section{DAFTAR PUSTAKA}

Ariesta, 2013. Uji Efektivitas Larutan Daun Pepaya (carica papaya) Sebagai Larvasida Terhadap Kematian Larva Aedes Aegypti di Laboratorium B2P2VRP. Semarang: Udinus.

Angger,L. 2017. Uji Daya Proteksi Ekstrak Daun Pepaya ( Carica Papaya L) Dalam Sediaan Lotion Dengan Basis Peg400 Sebagai Repellent Terhadap Aedes aegypty.

Barrera, R., M. Amador \& G. G. Clark. 2006. Ecological Factors Influencing Aedes aegypti (Diptera: Culicidae) Productivity in Artificial Containers in Salinas, Puerto Rico. J. Med. Entomol. 43(3): 484-492

Budiarto, E., Anggraeni,E. 2003. Pengantar Epidemiologi2. Jakarta: Buku Kedokteran EGC.

De Oliveira, S.G., Berchielli, T.T., Pedreira, M.S., Primavesi, O., Frighetto, R., Lima, M.A., 2007. Effect of tannin levels in sorghum silage and concentrate supplementation on apparent digestibility and methane emission in beef cattle. Anim. Feed Sci. Technol. 135, 236-248.

Dinas Kesehatan Kab. Jember. 2017. Kasus Demam Berdarah Dengue (DBD) Se Kab. Jember. Jember : Dinas Kesehatan Kab. Jember.

Enis Wilda Ningsi, 2016. Efektivitas Uji Daya Bunuh Ekstrak Daun Pepaya (Carica Papaya L.) Terhadap Larva Nyamuk Anopheles Aconitus Donits Dalam Upaya Pencegahan Penyakit Malaria Di Daerah Persawahan Desa Lalonggombu Kecamatan Andoolo Kabupaten Konawe Selatan. Fakultas Kesehatan Masyarakat Universitas Halu Oleo.

Hidayah, N. 2016. Pemanfaatan Senyawa Metabolit Sekunder Tanaman (Tanin dan Saponin) dalam Mengurangi Emisi Metan Ternak Ruminansia. Bengkulu.

Harborne, J. B. 1987. Metoda Fitokimia, Penuntun Cara Modern Menganalisa Tumbuhan. Terbitan ke-2. Terjemahan Kosasih Padmawinata dan Iwang Soediro. Bandung: Penerbit ITB.

Jannah, S, N., dan Lunggani, A, T. 2009. Pengaruh Ekstrak daun Teklan (Eupatorium riparium) terhadap Mortalitas dan Perkembangan Larva Aedes aegypti. Vol 11, No. 1. 
Restu Prastiwi, Anita Dewi Moelyaningrum, Prehatin T.N

Kondo, M., K. Kita And H. Yokota. 2004. Feeding value to goats of whole-crop oat ensiled with green tea waste. Anim. Feed Sci. Technol. 113: 71-81.

Melati,M. 2015. Potensi Tanin Dari Ekstraksi Daun Pepaya Dengan Pelarut Etanol. Universitas Muhammadiyah Jakarta.

Moelyaningrum. 2018. Penggunaan Serbuk buah pare (momordicha charantia L) terhadap kematian larva aedes aegypti. Jurnal Kesehatan Lingkungan Vol 4, Hal. 6. Journal UIN ALAUDIN Makassar

Najib R, 2017. Penggunaan Ekstrak Biji Pepaya (Carica Papaya) Dan Biji Alpukat (Persea Americana Mill) Sebagai Larvasida Aedes Aegypty.

Notoatmojo. 2015. Metodologi Penelitian. Kesehatan. Jakarta: Rineka Cipta

P.Malathi, 2015. Evaluation of mosquito larvicidal effect of Carica Papaya against Aedes Aegypti. P.G and Research, Department of Zoology Periyar E.V.R College (Autonomous) Thiruchirappalli23, Tamil Nadu, India 